\title{
Pengaruh Akuisisi Grab kepada Uber dan Citra Perusahaan (Corporate Image) terhadap Keputusan Penggunaan Jasa Transportasi Online (Studi Kasus Masyarakat Pertamburan Pengguna Jasa Transaportasi Online)
}

\author{
Oleh: \\ Ana Ramadhayanti \\ Universitas BSI Bandung \\ Email: ana.rdx@bsi.ac.id
}

\begin{abstract}
ABSTRAK
Di Indonesia khususnya Jakarta terdapat beberapa macam transportasi online seperti Grab, Uber dan Go-Jek. Seiring dengan munculnya berbagai macam ojek online membuat masyarakat memilih dari berbagai macam transportasi online tersebut yang sesuai dengan keinginannya, dan ini tentunya akan membuat persaingan diantara transportasi online tersebut. Siapa yang bertahan menghadapi persaingan maka, dialah yang menjadi pemenang. Seperti salah satunya yang terjadi antara Grab dan Uber. Grab telah mengakuisisi Uber yang tentunya akan menimbulkan Citra Perusahaan di masyarakat. Dengan berbagai uraian yang telah penulis tuangkan diatas, maka peneliti tertarik untuk melakukan penelitian ini dengan menggunakan jenis penelitian penjelasan (explanatory research) yang merujuk pada pendekatan kuantitatif dan menggunakan metode penelitian survei dengan cara membagikan kuesioner kepada pengguna transportasi online. Dari hasil penelitian menunjukkan bahwa Akuisisi Grab kepada Uber memiliki pengaruh yang signifikan dan positif. Begitu juga Citra Perusahaan memiliki pengaruh yang signifikan dan positif terhadap keputusan penggunaan transportsi online.
\end{abstract}

Kata Kunci: Grab, Uber, Transportasi Online, Akuisisi

\section{ABSTRACT}

In Indonesia, especially Jakarta there are several kinds of online transportation such as Grab, Uber and Go-Jek. Along with the emergence of a variety of online taxis make the people choose from a variety of online transport that is in line with their wishes, and this will certainly create competition among online transportation. One Who survived the competition then he was the winner. Like one of the things that happened between Grab and Uber. Grab has acquired an Uber that will certainly generate a corporate image in the community. With the various descriptions that the authors pour on the above, the researchers are interested in doing this research by using explanatory research which refers to quantitative approaches and using survey research methods by distributing questionnaires to online transportation users. From the results of the study, the Grab Acquisition to Uber has a significant and positive influence. Similarly, Corporate Image has a significant and positive influence on the decision of online transport use.

Keywords: Grab, Uber, Online Transportation, Acquisition

\section{I.PENDAHULUAN}

\subsection{Latar Belakang}

Perkembangan transportasi online saat ini telah berkembang pesat seiring dengan perkembangan Jaman. Salah satu perkembangan nyata yang saat ini berkembang pesat adalah transportasi ojek online yang dipesan melalui handphone. Antusiasme masyarakat terhadap permbangan transportasi ini sangatlah baik. Hal ini dibuktikan dengan banyaknya masyarakat 
yang saat ini beralih dari transportasi angkutan umum Koperasi Wahana Kalpika (KWK) dan sejenisnya ke angkutan transportasi online. Transportasi online sampai saat ini masih diminati oleh masyarakat, karena selain harganya yang murah transportasi ini juga sangat efektif jika berbicara mengenai waktu. Dengan angkutan ojek online ini masyarakat dapat datang ke tempat tujuan dengan waktu cepat dan tentunya tidak pakai proses tawar-menawar dalam menentukan soal harga. Selain berbagai manfaat yang mengutungkan dari transportasi online ini masayarakat juga masih diberikan keuntungan dengan banyaknya promo atau diskon dalam melakukan pembayaran transportasi online.

Saat ini kita mengenal transportasi online di Asia Tenggara khususnya Indonesia ada tiga jenis yang pertama yakni GO-JEK, GRAB, dan UBER. Ketiga transportasi ini memang saling mencuri perhatian konsumen dengan cara menawarkan berbagai promo atau diskon. Namun di luar dari itu ternyata masyarakat memiliki penilaian tersendiri dari ketiga transportasi tersebut. Seakan saling berlomba-lomba dalam mencari perhatian konsumen sehingga membuat ketiga angkutan ini saling membagikan promo atau diskon dalam menarik minat pasar. Meskipun demikian masyarakat tetap yang memiliki keputusan dalam memilih ketiga transportasi online ini.

Seiring dengan penilaian masyarakat dan pelayanan yang diberikan dari ketiga transportasi online ini salah dari transportasi online tersebut dibeli sahamnya oleh transportasi lain. Seperti dilansir dalam Kompas.com bahwa perusahaan penyedia teknologi penyedia transportasi daring, Uber resmi diakusisi kompetitornya, Grab, Senin (26/318). Melalui kesepakatan tersebut, semua aset serta pangsa pasar Uber yang ada di Asia Tenggra akan dikuasai Grab dan menjadikannya sebgai pemaian di bisnis transportasi daring terbesar untuk kawan tersebut.

Dengan pengambilalihan saham yang dilakukan Grab kepada Uber, tentunya menimbulkan persepsi tersendiri di masyarakat. Hal ini tentunya tidak dapat dipungkiri karena Uber cukup lama berdiri yakni sejak tahun 2009. Gambar 1.1. menunjukkan persentase pengguna aplikasi transportasi online di Indonesia. Berdasarkan informasi yang disajikan dari (Katadata News and Research, 2016) dalam grafik tersebut terlihat bahwa Grab lebih unggul daripada Uber, dengan perolehan skor 66,24\% untuk Grab dan 50,06\% untuk Uber.

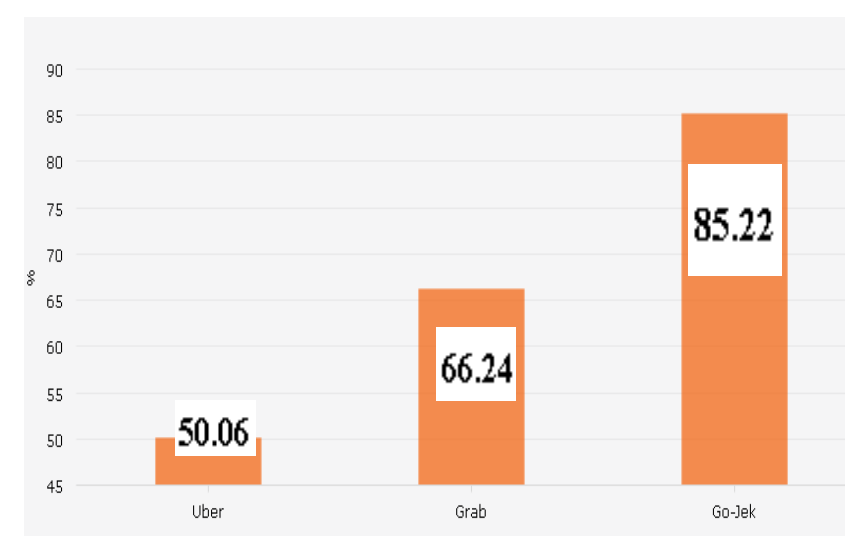

Gambar 1.1. Persentase Pengguna Aplikasi Transportasi Online di Indonesia Sumber: (Katadata News and Research, 2016) 
Dengan Akusisi yang dilakukan Grab kepada Uber tentunya mempengaruhi citra perusahaan yang pada akhirnya akan menimbulkan persepsi khalayak khususnya dalam menggunakan jasa transportasi online.

\section{LANDASAN TEORI}

\subsection{Restrukturisasi Perusahaan}

Sjahrial (2007:329) adalah suatu perusahaan dapat secara efektif memperoleh perusahaan lain dengan membeli sebagian besar atau semua aktiva-aktivanya. Setelah merger, perusahaan yang dibeli akan kehilangan/berhenti beroperasi (Harianto dan Sudomo, 2001). Sedangkan akuisisi adalah pengambil-alihan (takeover) sebuah perusahaan dengan membeli saham atau aset perusahaan tersebut, perusahaan yang dibeli tetap ada. (Brealey,et.al, 1999). Jenis-jenis Merger dan Akuisisi Menurut Damodaran (2001) yaitu:

1. Merger

Pada merger, para direktur kedua pihak setuju untuk bergabung dengan persetujuan para pemegang saham. Pada umumnya, penggabungan ini disetujui oleh paling sedikit $50 \%$ shareholder dari target firm dan bidding firm. Pada akhirnya target firm akan menghilang (dengan atau tanpa proses likuidasi) dan menjadi bagian dari bidding firm.

2. Konsolidasi

Setelah proses merger selesai, sebuah perusahaan baru tercipta dan pemegang saham kedua belah pihak menerima saham baru di perusahaan ini

3. Tender Offer

Terjadi ketika sebuah perusahaan membeli saham yang beredar di perusahaan lain tanpa persetujuan manajemen target firm, dan disebut tender offer karena merupakan hostile takeover. Target firm akan tetap bertahan selama tetap ada penolakan terhadap penawaran. Banyak tender offer yang kemudian berubah menjadi merger karena bidding firm berhasil mengambil alih kontrol target firm.

4. Acquisitions of Assets

Sebuah perusahaan membeli aset perusahaan lain melalui persetujuan pemegang saham target firm.

\subsection{Citra Perusahaan}

Gou (2011:1876) berpendapat bahwa citra perusahaan adalah sekumpulan persepsi oleh konsumen terhadap perusahaan yang membuat suatu produk atau jasa yang meliputi kredibilitas perusahaan, jaringan distribusi perusahaan maupun popularitas perusahaan. Citra perusahaan adalah pemikiran pelanggan tentang citra atau gambaran menyeluruh dari perusahaan penyedia jasa berdasarkan pengalaman dan pemahaman pelanggan masingmasing, baik menyangkut jasanya ataupun tingkat reputasi dan kredibilitas yang dicapai perusahaan menurut persepsi pelanggan (Ratih, 2009).

Citra perusahaan yang baik tidak dapat dibeli tapi didapat oleh perusahaan-perusahaan yang memiliki reputasi bagus umumnya memiliki enam hal, yaitu (Anggoro, 2000) :

a. Hubungan baik dengan pemuka masyarakat.

b. Hubungan positif dengan pemerintah setempat.

c. Resiko krisis yang lebih baik.

d. Rasa kebanggaan dalam organisasi dan diantara khalayak sasaran.

e. Saling pengertian antara khalayak sasaran baik internal maupun eksternal.

f. Meningkatkan kesetiaan para staff perusahaan. 


\subsection{Keputusan Menggunakan}

Pada dasarnya keputusan pembelian memiliki makna yang sama dengan keputusan menggunakan. Pengambilan keputusan konsumen adalah proses pengintegrasian yang mengkombinasikan pengetahuan untuk mengevaluasi dua atau lebih perilaku alternatif dan memilih salah satu diantaranya (Setiadi, 2010). Menurut (Kotler \& Armstrong, 2008) adalah tahap dalam proses pengambilan keputusan pembeli dimana konsumen benar-benar membeli, Menurut (Schiffman \& Kanuk, 2008). Secara umum, keputusan adalah pemilihan dari dua atau lebih alternatif pilihan dan menurut (Suhari, 2008) keputusan pembelian online merupakan proses seorang konsumen menggunakan media internet untuk melakukan pembelian sebuah produk atau jasa dimulai dengan timbulnya awareness (kesadaran) konsumen akan suatu informasi atau produk yang dapat diperoleh dari internet.

Indikator Keputusan Pembelian Indikator dari keputusan pembelian (Soewito, 2013) :

a) Kebutuhan yang dirasakan

b) Kegiatan sebelum membeli

c) Perilaku waktu memakai

d) Perilaku pasca pembelian

\subsection{Kerangka Berfikir}

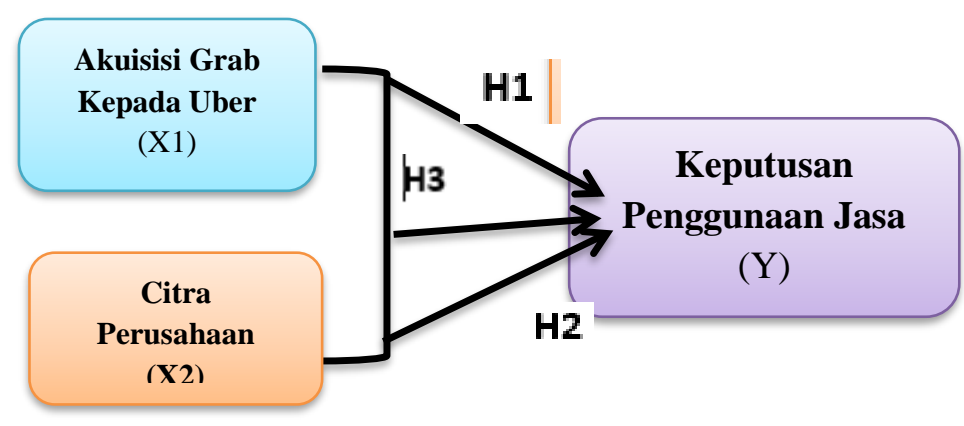

Gambar 2.1. Kerangka Berfikir

Sumber: Data diolah Peneliti

\section{METODE PENELITIAN}

Penelitian yang digunakan adalah penelitian penjelasan (explanatory research) dengan pendekatan kuantitatif dan menggunakan metode peneltian survei. Menurut Singarimbun dan Effendi (2006:5) explanatory research di definisikan sebagai penelitian yang menjelaskan tentang hubungan kausal antara variabel-variabel melalui pengujian hipotesa.

Teknik sampling yang digunakan dalam penelitian ini adalah purposive sampling, yaitu teknik pengambilan sample dengan cara peneliti memilih sample purposive atau sample bertujuan secara subjektif. Lokasi penelitian yang dipilih adalah Pertamburahan Kelurahan Tanah Abang Jakarta Pusat. Sementara itu untuk mengetahuai jumlah warga masyarakat pertamburan, peneliti mengambil data dari BPS 2017 dengan menggunakan rumus Slovin. 
$\mathrm{net}_{\mathrm{Ket}}=\frac{N}{1+N e^{2}}$

$\mathrm{n}=$ jumlah sampel

$\mathrm{N}=$ jumlah populasi

$\mathrm{e}=$ batas toleransi kesalahan (error tolerance)

$n=\frac{38.425}{1+38.425 \times 0,05^{2}}$

$n=\frac{38.425}{38.426 \times 0,0025}$

$n=\frac{38.425}{96,065}$

$x=399,98959$ dibulatkan menjadi (400)

\subsection{Hipotesis Penelitian}

Berdasarkan dari hasil teoritis yang sebelumnya telah peneliti sajikan diatas maka, peneliti membuat hipotesa atau dugaan sementara dari ketiga variabel yang diteliti. Pada dasarnya menurut Malhotra (2005:56) hipotesis adalah pertanyaan atau proposisi yang belum dibuktikan mengenai faktor atau fenomena yang menjadi minat peneliti.

$\mathrm{H}_{0}$ : Tidak ada hubungan antara Akuisisi Grab kepada Uber (X1) terhadap Keputusan Penggunaan Jasa Transportasi Online (Y)

Ha : Ada hubungan antara Akuisisi Grab kepada Uber (X1) terhadap Keputusan Penggunaan Jasa Transportasi Online (Y)

$\mathrm{H}_{0}$ : Tidak ada hubungan antara Citra Perusahaan (X2) terhadap Keputusan Penggunaan Jasa Transportasi Online (Y)

Ha : Ada hubungan antara Citra Perusahaan (X2) terhadap Keputusan Penggunaan Jasa Transportasi Online (Y)

\subsection{Variabel Penelitian}

Dalam menyebarkan kuesioner peneliti menggunakan skala pengukuran "Likert" dengan masing-masing butir pertanyaan memiliki skor sebagai berikut :

1. Skor 5 untuk jawaban Sangat Setuju (SS)

2. Skor 4 untuk jawaban Setuju (S)

3. Skor 3 untuk jawaban Kurang Setuju (KS)

4. Skor 2 untuk jawaban Tidak Setuju (TS)

5. Skor 1 untuk jawaban Sangat Tidak Setuju (STS)

Menurut Hidayat (2007) variabel secara operasional berdasarkan karakteristik yang diamati yang memungkinkan peneliti untuk melakukan observasi atau pengukuran secara cermat terhadap suatu objek atau fenomena. Menurut (Sugiyono, 2013) Variabel Independen adalah variabel yang memengaruhi atau yang menjadi sebab perubahannya atau timbulnya variabel dependen. Dalam penelitian ini variabel independen adalah Akusisi Grab kepada Uber (X1)

Sementara itu menurut (Sugiyono, 2013) Variabel terikat merupakan variabel yang dipengaruhi atau yang menjadi akibat, karena adanya variabel begas. Dalam hal ini variabel dependena adala Keputusan Penggunaan Trasportasi Online (Y). Menurut (Kadji, 2016) 
menjelaskan Variasi sifat-sifat dari variabel itu dinyatakan dengan dimensi atau indikator. Dimensi atau indikator itu lebih konkrit dari variabel (ingat, bahwa variabel konsep, adalah abstraksi atau indikator itu adalah penjelasan atau ciri-ciri yang menggambarkan variabel itu). Berdasarkan beberapa teoritis yang peneliti lakukan mengenai Variabel, Dimensi dan Indikator berikut ini penjabran dari masing-masing yang telah penulis buat dalam Tabel 3.1.

Tabel 3.1. Variabel, Dimensi dan Indikator

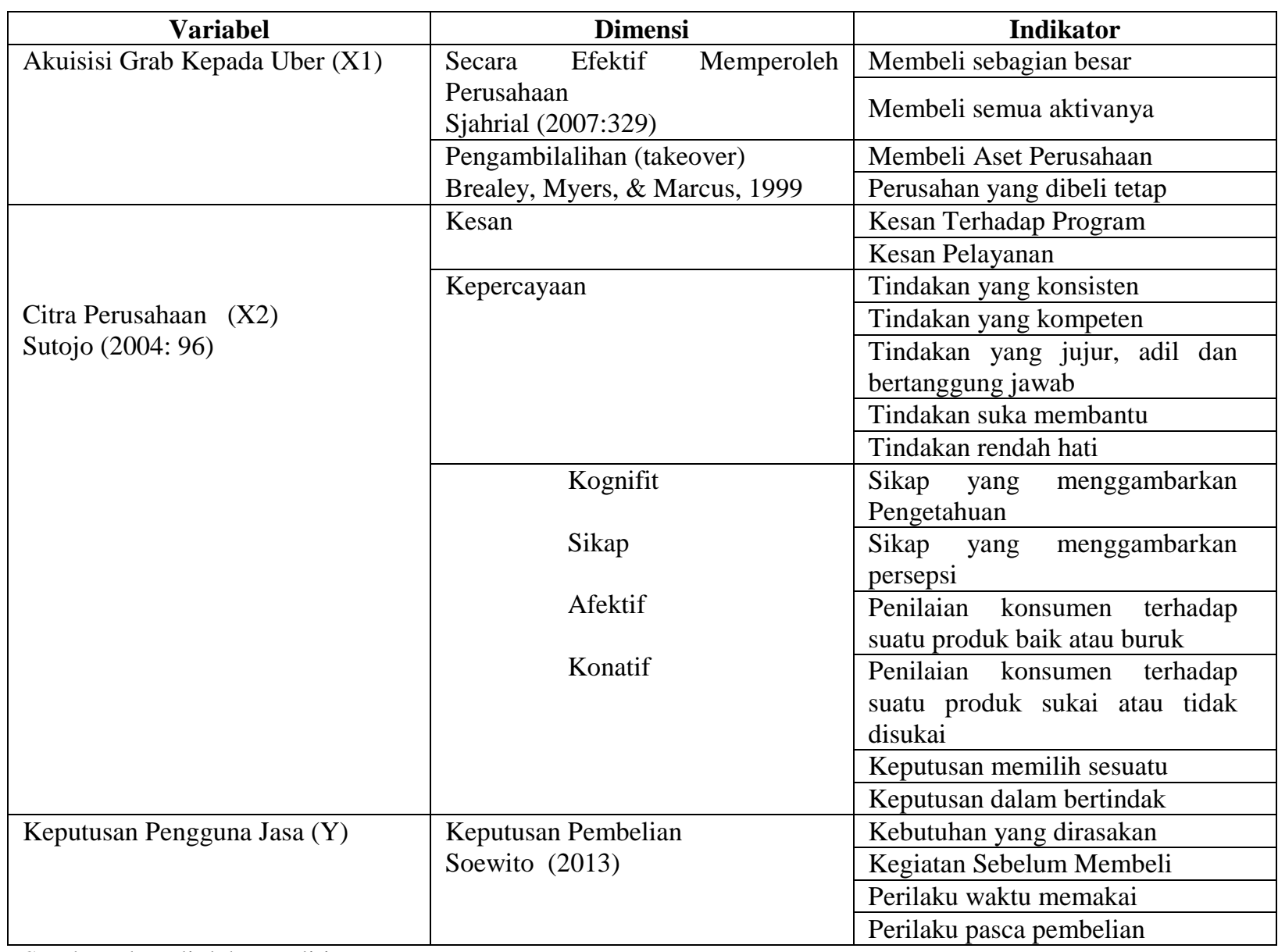

Sumber: data diolah Peneliti

\section{IV.PEMBAHASAN}

\subsection{Uji Validitas}

Tabel 4.1 Uji Validitas Akuisisi Grab Kepada Uber

\begin{tabular}{cccc}
\hline No. & $\begin{array}{c}\text { r hitung } \\
\text { Akuisisi Grab } \\
\text { Kepada Uber } \\
(\mathbf{X 1})\end{array}$ & r tabel & Keterangan \\
\hline 1. & 0,876 & 0,098 & Valid \\
\hline 2. & 0,828 & 0,098 & Valid \\
\hline 3. & 0,826 & 0,098 & Valid \\
\hline 4. & 0,681 & 0,098 & Valid \\
\hline 5. & 0,836 & 0,098 & Valid \\
\hline 6. & 0,943 & 0,098 & Valid \\
\hline 7. & 0,733 & 0,098 & Valid \\
\hline 8. & 0,884 & 0,098 & Valid \\
\hline
\end{tabular}

Sumber: Data yang diolah dengan SPSS $25(2018)$ 
Tabel 4.2 Uji Validitas Citra Perusahaan (X2)

$\begin{array}{ccc}\text { No. } & \mathbf{r} \text { hitung Citra } \\ \text { Perusahaan } & \mathrm{r} \text { tabel } & \text { Keterangan }\end{array}$

\begin{tabular}{cccc}
\multicolumn{5}{c}{$(\mathbf{X 2 )}$} & & \\
\hline 1. & 0,871 & 0,098 & Valid \\
\hline 2. & 0,829 & 0,098 & Valid \\
\hline 3. & 0,838 & 0,098 & Valid \\
\hline 4. & 0,667 & 0,098 & Valid \\
\hline 5. & 0,832 & 0,098 & Valid \\
\hline 6. & 0,917 & 0,098 & Valid \\
\hline 7. & 0,723 & 0,098 & Valid \\
\hline 8. & 0,891 & 0,098 & Valid
\end{tabular}

Sumber: Data yang diolah dengan SPSS $25(2018)$

Tabel 4.3. Uji Validitas Keputusan Penggunaan Jasa (Y)

\begin{tabular}{cccc}
\hline No. & $\begin{array}{c}\text { r hitung } \\
\text { Keputusan } \\
\text { Penggunaan } \\
\text { Jasa } \\
(\mathbf{Y})\end{array}$ & r tabel & Keterangan \\
\hline 1. & 0,872 & 0,098 & Valid \\
\hline 2. & 0,820 & 0,098 & Valid \\
\hline 3. & 0,836 & 0,098 & Valid \\
\hline 4. & 0,656 & 0,098 & Valid \\
\hline 5. & 0,840 & 0,098 & Valid \\
\hline 6. & 0,929 & 0,098 & Valid \\
\hline 7. & 0,723 & 0,098 & Valid \\
\hline 8. & 0,892 & 0,098 & Valid \\
\hline
\end{tabular}

Sumber: Data yang diolah dengan SPSS 25 (2018)

Berdasarkan hasil perhitungan validitas dari tiga variabel yang diteliti menujukkan hasilnya adalah valid karena nilai $r_{\text {hitung }}>r_{\text {tabel }}$. Menurut (Widiyanto 2014, 305) menjelaskan item dinyatakan valid jika koefisien $r_{\text {hitung }}$ lebih besar dari $\mathrm{r}_{\text {tabel }}$

\subsection{Uji Heteroskedastisitas}

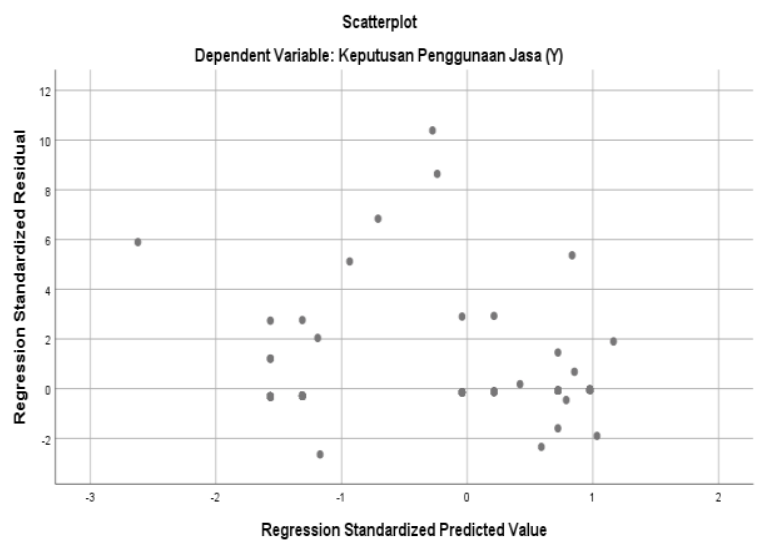

Gambar 4.1. Uji Heteroskedastisitas

Sumber: Data yang diolah dengan SPSS 25 (2018)

Dari gambar 4.1. diketahui bahwa tidak terjadi Heteroskedastisitas. Hal ini sesuai teori (Wijaya, 2012) yang menjelaskan bahwa dengan melihat sebaran titik-titik yang acak baik di atas maupun di bawah angka 0 dari sumbu Y, dapat disimpulkan dari gambar 4.1. dibawah ini tidak terjadi Heteroskedastisitas dalam model regresi ini. 


\subsection{Uji Realibilitas}

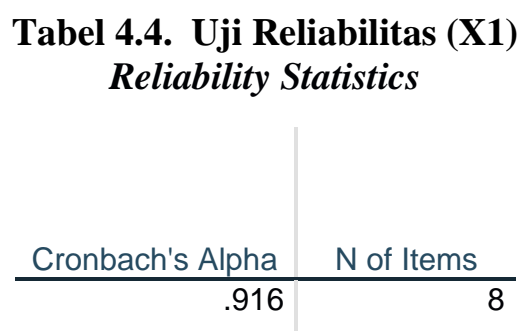

Sumber: Data yang diolah dengan SPSS 25 (2018)

Tabel 4.5. Uji Reliabilitas (X2)

Reliability Statistics

\begin{tabular}{r|rr} 
Cronbach's Alpha & & N of Items \\
\hline .913 & & 8 \\
\hline
\end{tabular}

Sumber: Data yang diolah dengan SPSS 25 (2018)

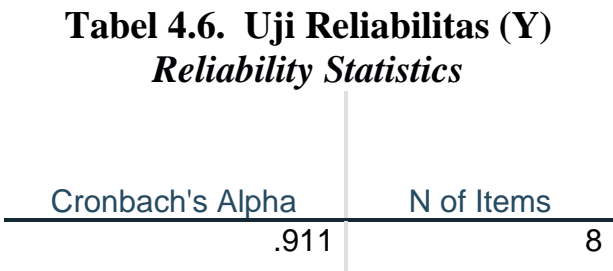

Sumber: Data yang diolah dengan SPSS 25 (2018)

Berdasarkan hasil perhitungan reliabilitas untuk ketiga variabel diatas, maka dapat disimpulkan bahwa hasil uji Reliabilitas adalah Cronbach's Alpha yang sangat tinggi yakni diatas 0,900. Menurut (Widiyanto, 2014) sebuah instrumen dinyatakan memiliki keandalan atau reliabilitas yang tinggi jika koefisien reliabilitasnya lebih besar dari 0,7.

\subsection{Uji T}

Menurut (Priyatno, 2013) Uji t untuk mengetahui pengaruh variabel independen secara parsial terhadap variabel dependen, apakah pengaruhnya signifikan atau tidak.

\subsubsection{Pengujian b1 (Akuisisi Grab Kepada Uber)}

Tahap-tahap pengujian sebagai berikut:

a. Menentukan hipotesis nol dan hitopesis alternatif

$\mathrm{H}_{0}: \mathrm{b} 1=0$

Artinya Akuisisi Grab kepada Uber tidak berpengaruh Terhadap Keputusan Penggunaan Jasa

$\mathrm{H}_{\mathrm{a}}: \mathrm{b} 1 \neq 0$

Artinya Akuisisi Grab kepada Uber berpengaruh Terhadap Keputusan Penggunaan Jasa.

b. Menentukan taraf signifikansi. Taraf signifikansi menggunkan 0,05.

c. $t$ hitung dan $t$ kritis 
t hitung adalah 9,862 (lihat di tabel 4.5. Coefficients) t kritis dapat dicari pada tabel statistik pada signifikansi $0,05 / 2=0,025$ (uji 2 sisi) dengan df $=n-k-1$ atau $400-2-1$ $=397$ ( $\mathrm{k}$ adalah jumlah variabel independen). Di dapat $\mathrm{t}$ kritis 1,966.

d. Pengambilan keputusan

$\mathrm{T}$ hitung $\leq \mathrm{t}$ kritis jadi $\mathrm{H}_{0}$ diterima

$\mathrm{T}$ hitung > t kritis jadi $\mathrm{H}_{0}$ ditolak

e. Kesimpulan

Dapat diketahui bahwa $\mathrm{t}$ hitung 9,862 >t kritis $(1,966)$ jadi hipotesis nol ditolak, kesimpulannya yaitu menujukkan Akuisisi Grab kepada Uber berpengaruh terhadap Keputusan Penggunaan Jasa. Nilai koefisien dan t hitung adalah positif sehingga Akuisisi Grab kepada Uber berpengaruh positif terhadap Keputusan Penggunaan Jasa.

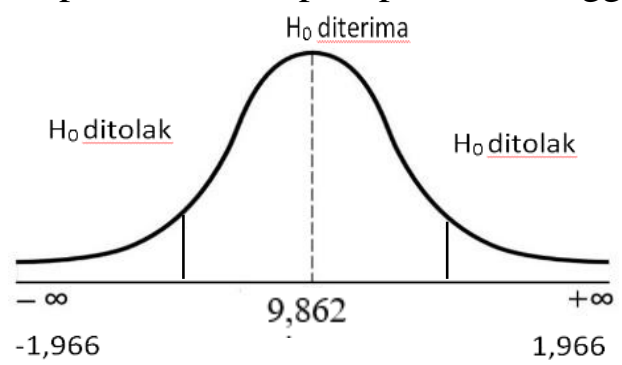

Gambar 4.2. Distribusi Normal Pada X1

Sumber: Data yang diolah dengan SPSS 25 (2018)

Pengambilan keputusan berdasarkan Probabilitas (Signifikansi)

a. Menentukan hipotesis nol dan hipotesis alternatif

$$
\mathrm{H}_{0}: \mathrm{b}_{2}=0
$$

Artinya Akuisisi Grab kepada Uber tidak berpengaruh terhadap Keputusan Penggunaan Jasa

$\mathrm{H}_{0}: \mathrm{b}_{2} \neq 0$

Artinya Akuisisi Grab kepada Uber berpengaruh terhadap Keputusan Penggunaan Jasa

b. Menentukan probalibilitas (signifikasi) berdasarkan tabel Coefficients dapat diketahui probabilitas adalah 0,000

c. Pengambilan keputusan

Probabilitas $>0,05$ jadi $\mathrm{H}_{0}$ diterima

Probabilitas $\leq 0,05$ jadi $\mathrm{H}_{0}$ ditolak

d. Kesimpulan

Dapat diketahui bahwa Probabilitas sebesar 0,000 lebih kecil dari 0,05 maka hipotesis nol ditolak, kesimpulannya yaitu Akuisisi Grab kepada Uber berpengaruh terhadap Keputusan Penggunaan Jasa.

\subsubsection{Pengujian b2 (Citra Perusahaan)}

Tahap-tahap pengajuan sebagai berikut:

a. Menentukan hipotesis nol dan hitopesis alternatif

$\mathrm{H}_{0}: \mathrm{b} 1=0$

Artinya Citra Perusahaan tidak berpengaruh terhadap Keputusan Penggunaan Jasa

$\mathrm{H}_{\mathrm{a}}: \mathrm{b} 1 \neq 0$

Artinya Citra Perusahaan berpengaruh terhadap Keputusan Penggunaan Jasa.

b. Menentukan taraf signifikansi. Taraf signifikansi menggunkan 0,05.

t hitung dan $\mathrm{t}$ kritis

t hitung adalah 27,113 (lihat di tabel 4.5. Coefficients) 
t kritis dapat dicari pada tabel statistik pada signifikansi $0,05 / 2=0,025$ (uji 2 sisi) dengan df $=\mathrm{n}-\mathrm{k}-1$ atau 400-2-1 =397 ( $\mathrm{k}$ adalah jumlah variabel independen). Di dapat $\mathrm{t}$ kritis 1,966 .

d. Pengambilan keputusan

$\mathrm{T}$ hitung $\leq \mathrm{t}$ kritis jadi $\mathrm{H}_{0}$ diterima

$\mathrm{T}$ hitung $>\mathrm{t}$ kritis jadi $\mathrm{H}_{0}$ ditolak

e. Kesimpulan

Dapat diketahui bahwa t hitung 9,862 >t kritis $(1,966)$ jadi hipotesis nol ditolak, kesimpulannya yaitu Citra Perusahaan berpengaruh terhadap Keputusan Penggunaan Jasa.

Nilai koefisien dan t hitung adalah positif sehingga Citra Perusahaan berpengaruh positif terhadap Keputusan Penggunaan Jasa.

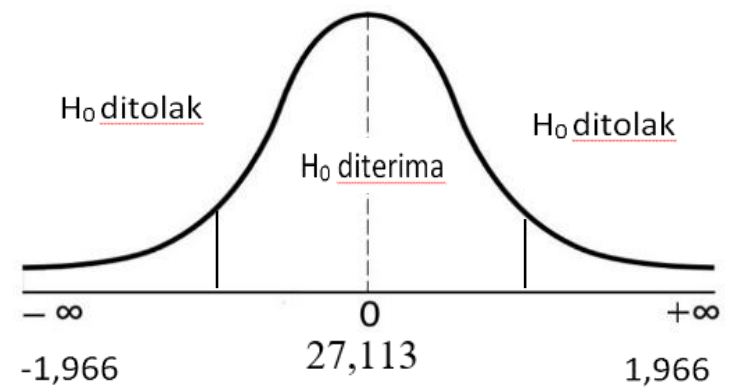

Gambar 4.3. Distribusi Normal Pada X2

Sumber: Data yang diolah dengan SPSS 25 (2018)

Pengambilan keputusan berdasarkan Probabilitas (Signifikansi)

a. Menentukan hipotesis nol dan hipotesis alternatif

$\mathrm{H}_{0}: \mathrm{b}_{2}=0$

Artinya Citra Perusahaan tidak berpengaruh terhadap Keputusan Penggunaan Jasa

$\mathrm{H}_{0}: \mathrm{b}_{2} \neq 0$

Artinya Citra Perusahaan berpengaruh terhadap Keputusan Penggunaan Jasa

b. Menentukan probalibilitas (signifikasi) berdasarkan tabel Coefficients dapat diketahui probabilitas adalah 0,000

c. Pengambilan keputusan

Probabilitas $>0,05$ jadi $\mathrm{H}_{0}$ diterima

Probabilitas $\leq 0,05$ jadi $\mathrm{H}_{0}$ ditolak

d. Kesimpulan

Dapat diketahui bahwa Probabilitas sebesar 0,000 lebih kecil dari 0,05 maka hipotesis nol ditolak, kesimpulannya yaitu Citra Perusahaan berpengaruh terhadap Keputusan Penggunaan Jasa.

Tabel 4.7. UJI T

\begin{tabular}{|c|c|c|c|c|c|c|c|c|}
\hline \multicolumn{9}{|c|}{ Coefficients $^{\mathrm{a}}$} \\
\hline \multirow[b]{2}{*}{ Model } & & \multicolumn{2}{|c|}{$\begin{array}{l}\text { Unstandardized } \\
\text { Coefficients }\end{array}$} & \multirow{2}{*}{$\begin{array}{c}\text { Standardize } \\
d \\
\text { Coefficients } \\
\text { Beta }\end{array}$} & \multirow[b]{2}{*}{$\mathrm{t}$} & \multirow[b]{2}{*}{ Sig. } & \multicolumn{2}{|c|}{$\begin{array}{c}\text { Collinearity } \\
\text { Statistics }\end{array}$} \\
\hline & & B & Std. Error & & & & $\begin{array}{c}\text { oleranc } \\
\mathrm{e}\end{array}$ & VIF \\
\hline 1 & (Constant) & .693 & .279 & & 2.485 & .013 & & \\
\hline & $\begin{array}{l}\text { Akuisisi Grab Kepada } \\
\text { Uber (X1) }\end{array}$ & .255 & .026 & .266 & 9.862 & .000 & .097 & 10.332 \\
\hline & $\begin{array}{l}\text { Citra Perusahaan } \\
\text { (X2) }\end{array}$ & .727 & .027 & .730 & 27.113 & .000 & 097 & 10.332 \\
\hline
\end{tabular}


a. Dependent Variable: Keputusan Penggunaan Jasa $(Y)$

Sumber: Data yang diolah dengan SPSS 25 (2018)

\subsection{Uji F}

Menurut (Baroroh, 2008) menjelaskan bahwa (Uji F disebut juga dengan uji ANOVA, yaitu Analysist of Variance. Kegunaan Uji F hampir sama dengan uji t, yaitu untuk menganalisis ada tidaknya perbedaan rata-rata atau nilai tengah suatu data. Namun perbedaannya hanya pada kelompok datanya, dimana pada uji $\mathrm{F}$ kelompok data yang diuji dapat lebih dari dua kelompok. Pada perkembangannya, uji F paling sering digunakan untuk analisis rancangan percobaan (Experimental Design). Di mana pada analisis ini, selain menganalisis pengaruh kelompok juga dapat menganalisis setiap perlakuan yang ada pada setiap kelompok tersebut. Untuk menganalisis ada tidaknya perbedaan atau pengaruh tersebut dalam uji F, dibutuhkan suatu nilai standar atau nilai $\mathrm{F}$ tabel sebagai pembanding.

Menurut (Santoso, 2005) ANOVA sering juga disebut dengan uji F. Tujuan ANOVA (analisis varian) sama dengan uji t, yakni menguji rata-rata populasi, hanya di sini yang akan diuji lebih dari dua rata-rata populasi. Sedangkan tujuan dari uji $\mathrm{F}$ adalah untuk menguji apakah varian dua populasi sama ataukah berbeda. Hasil data perhitungan menggunakan SPSS didapatkan Nilai F tabel sebesar 3,01 karena nilai $F$ hitung 6925,734 lebih besar dari nilai $\mathrm{F}$ tabel 3,01 maka dapat ditarik kesimpulan bahwa variabel bebas X1.

Tabel 4.8. UJI F

\begin{tabular}{|c|c|c|c|c|c|c|}
\hline \multicolumn{7}{|c|}{ ANOVA $^{a}$} \\
\hline Model & & Sum of Squares & df & Mean Square & $\mathrm{F}$ & Sig. \\
\hline \multirow[t]{3}{*}{1} & Regression & 5953.833 & 2 & 2976.917 & 6925.734 & $.000^{\mathrm{b}}$ \\
\hline & Residual & 170.644 & 397 & .430 & & \\
\hline & Total & 6124.477 & 399 & 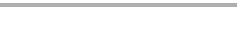 & & \\
\hline
\end{tabular}

\subsection{Uji Regresi}

Nilai R menujukkan korelasi berganda, yaitu korelasi antara dua atau lebih variabel independen terhdap variabel dependen. Nilai $\mathrm{R}$ berkisar antara 0 sampai 1 . Jika nilainya mendekati 1, maka hubungan semakin erat. Sebaliknya, jika mendekati 0, maka hubungan semakin lemah. Angka R didapat 0,986, artinya korelasi antara variabel Akuisisi Grab kepada Uber (X1) terhadap keputusan menggunakan transportasi online (Y) sebesar 0,986. Hal ini berarti terjadi hubungan yang sangat erat antara variabel X1 dan Y.

$R$ Square $\left(\mathrm{R}^{2}\right)$ atau kuadrat $\mathrm{R}$ menujukkan koefisien determinasi. Angka jika diubah menjadi persen yang berarti sumbangan pengaruh variabel independen terhadap variabel dependen. Nilai $\mathrm{R}^{2}$ sebesar 0,972 , artinya persentase sumbangan pengaruh variabel Akuisisi Grab kepada Uber (X1) terhadap keputusan sebesar 97,2\%, sedangkan sisa 2,8\% dipengaruhi oleh varibel lain yang tidak dimasukkan dalam model ini.

Adjusted $R$ Square adalah $R$ Square yang telah disesuaikan. Nilai yang diperoleh sebesar 0,972. Hal ini menujukkan sumbangan pengaruh variabel independen terhadap dependen. (Akusisi Grab Kepada Uber) dan X2 (Citra Perusahaan) secara bersama berpengaruh terhadap variabel terikat Y (Keselamatan Berkendara), seperti yang disajikan dalam tabel 4.9. 
Tabel 4.9. Uji Regresi

\begin{tabular}{|c|c|c|c|c|}
\hline \multicolumn{5}{|c|}{ Model Summary } \\
\hline Model & $\mathrm{R}$ & R Square & Adjusted R Square & Std. Error of the Estimate \\
\hline 1 & $.986^{\mathrm{a}}$ & .972 & .972 & .656 \\
\hline
\end{tabular}

\subsection{Uji Korelasi}

Korelasi antara “Akuisisi Grab Kepada Uber" dengan Keputusan Penggunaan Jasa (Y) memberikan nilai koefisien sebesar 959. Karena koefisien mendekati 1, maka dapat disimpulkan bahwa hubungan antara "Akuisisi Grab Kepada Uber" sangat erat. Sementara itu, korelasi antara "Citra Perusahaan" dengan "Keputusan Menggunakan Transportasi Online memberikan koefisien sebesar 0,983. Karena koefisien mendekati 1, maka dapat disimpulkan bahwa hubungan anatara "Citra Perusahaan" dengan "Keputusan Menggunakan Transportasi" Online sangat erat. Sementara itu angka koefisien positif menujukkan hubungan positif, yaitu jika Akuisisi Grab Kepada Uber meningkat maka Keputusan Menggunakan Transportasi Online juga akan meningkat dan jika Citra Perusahaan meningkat maka Keputusan Menggunakan Transportasi Online juga akan meningkat.

Tabel 4.10. Uji Korelasi

\begin{tabular}{|c|c|c|c|c|}
\hline \multicolumn{5}{|c|}{ Correlations } \\
\hline & & Keputusan & Akuisisi Grab & Citra \\
\hline & & $\begin{array}{l}\text { Penggunaan } \\
\text { Jasa }(Y)\end{array}$ & $\begin{array}{l}\text { Kepada Uber } \\
(\mathrm{X} 1)\end{array}$ & $\begin{array}{l}\text { Perusahaan } \\
(\mathrm{X} 2)\end{array}$ \\
\hline \multirow{3}{*}{$\begin{array}{l}\text { Keputusan Penggunaan } \\
\text { Jasa }(Y)\end{array}$} & Pearson Correlation & 1 & $.959^{\star *}$ & $.983^{* *}$ \\
\hline & Sig. (2-tailed) & & .000 & .000 \\
\hline & $\mathrm{N}$ & 400 & 400 & 400 \\
\hline \multirow{3}{*}{$\begin{array}{l}\text { Akuisisi Grab Kepada Uber } \\
\text { (X1) }\end{array}$} & Pearson Correlation & $.959^{* *}$ & 1 & $.950^{* *}$ \\
\hline & Sig. (2-tailed) & .000 & & .000 \\
\hline & $\mathrm{N}$ & 400 & 400 & 400 \\
\hline \multirow[t]{3}{*}{ Citra Perusahaan (X2) } & Pearson Correlation & $.983^{* *}$ & $.950^{* *}$ & 1 \\
\hline & Sig. (2-tailed) & .000 & .000 & \\
\hline & $\mathrm{N}$ & 400 & 400 & 400 \\
\hline
\end{tabular}

**. Correlation is significant at the 0.01 level (2-tailed).

Sumber: Data yang diolah dengan SPSS 25 (2018) 


\section{KESIMPULAN DAN SARAN}

\subsection{Kesimpulan}

Kesimpulan Berdasarakan dari hasil penelitian yang penulis lakukan menunjukkan hasil bahwa Akuisisi Grab kepada Uber memiliki pengaruh yang signifikan dan positif terhadap Keputusan Penggunaan Jasa Transportasi Online. Sementara itu untuk Citra Perusahaan terhadap Keputusan Penggunaan Jasa Transportasi Online memiliki pengaruh yang signifikan dan positif.

\subsection{Saran}

Semoga dari hasil penelitian ini masyarakat dapat terus menggunakan transportasi online, mengingat transportasi ini merupakan transportasi yang efektif dapat membantu masyarakat dalam kesibukannya. Selain itu dengan bersatunya Grab dan Uber ini semoga transportasi ini dapat lebih berkembang lagi pelayanan atau aplikasinya.

\section{DAFTAR PUSTAKA}

Alimul Hidayat, Aziz. 2009. Metode Penelitian Keperawatan dan Teknik Analisis Data. Jakarta: Salemba Medika

Anggoro, Lingar. 2000. Teori Profesi Kehumasan. Bandung: Bumi Aksara

Badan Pusat Sttaistik (BPS). 2017. Kecamatan Tanah Abang Dalam Angka 2017. Jakarta: BPS.

Baroroh, Ari. 2018. Trik-Trik Analisis Statistik Dengan SPSS 15 Jakarta:PT.Elex Media Komputindo.

Brealey, RA Myers,S.C., dan Marcus A.J. (1999). Fundamentals of Corporate Finance. Edisi Kedua. Irwin Mcgraw-Hill:Boston.

Damodaran, A Swath. (2001). Corporate Finance: Theory and Practice. Second edition. USA: John Wiley and Sons Inc.

Dermawan Sjahrial. 2007. Manajemen Keuangan. Jakarta: Mitra Wacana Media.

Gou Li Xian. 2011. Corporate, Product, and User Image Dimensions and Purchase Intentions. Journal of Computers, Departement of marketing School of business, Renmin University of China, Beijing, China

Harianto dan Sudomo. (2001). Merger dan Akuisisi. Jurnal Manejemen

https://databoks.katadata.co.id/datapublish/2018/02/12/go-jek-aplikasi-transportasi-onlinepaling-banyak-digunakan

Kadji, Yulianti. 2016. Metode Penelitian Ilmu Administrasi. Yogyakarta: Deepublish.

Kotler, Philip dan Keller, L Kevin. 2009. ManajemenPemasaran. Edisi 13.Jakarta : PT GeloraAksaraPratama

Kotler, P dan Keller.2007.Manajemen Pemasaran. Edisi Keduabelas.Jilid 2.PT Indeks.Indonesia. 
Pearce, John A dan Robinson Richard B. 2008. Manajemen Stategis-Formulasi, Implementasi, Dan Pengendalian, Edisi 10 Buku 1 Strategic Management-Formulation, Implementatition, And Control, $10^{\text {th }}$ Edition. Jakarta: Salemba Empat.

Priyatno, Duwi. 2013. Analisis Korelasi, Regresi Dan Multivariate Dengan SPSS.Yogyakarta: Gava Media

Ratih, Ida Aju Brahma. 2009. Pengaruh Kinerja Produk, Pelayanan dan Sumberdaya amnesia Terhadap Niat Pembelian Ulang Melalui Citra Perusahaan dan Kepuasan Pelanggan PT Asuransi Jiwasraya. Ekuitas. Vol. 13, no.2, p.176-198.

Santoso, Singgih. 2005. Menggunakan SPSS untuk Statistik Parametrik. Jakarta: Elex Media Komputindo

Setiadi, Nugroho. 2010. Perilaku Konsumen. Cetakan Keempat. Jakarta: Kencana Prenada Media Group.

Singarimbun, Masri dan Sofian Effendi. 2006. Metode Penelitian Survai. Jakarta: LP3ES.

Soewito, Yudhi. 2013. Kualitas Produk, Merek dan Desain Pengaruhnya Terhadap Keputusan Pembelian 227 - 242 Sepeda Motor Yamaha Mio. Jurnal Ekonomi. Vol.1, No.3 Juni 2013.

Sugiyono. (2013). Metode Penelitian Kuantitatif, Kualitatif dan R\&D.Bandung: Alfabeta.CV.

Suhari, Yohanes . 2008. Keputusan Pembelian Secara Online dan Faktor-Faktor yang mempengaruhi. Jurnal Teknologi Informasi. Vol. 8(2) : Hal. 140-146.

Sutojo, Siswanto. 2004. Membangun Citra Perusahaan. Jakarta : Damar Mulia Pustaka.

Wijaya, Tony. 2012. Cepat Menguasai SPSS 20 Untuk Olah Data Interprestasi Data. Yogyakarta: Cahaya Atma Pustaka. 